\title{
GOODWILL IN THE PROCESS OF MERGERS AND ACQUISITIONS IN POLAND
}

\author{
Piotr Luty \\ e-mail: piotr.luty@ue.wroc.pl \\ (C) 2018 Piotr Luty \\ DOI: 10.15611/fins.2018.2.02 \\ JEL Classification: G32, G34
}

Wrocław University of Economics, Wrocław, Poland

This is an open access article distributed under the Creative Commons Attribution-NonCommercial-NoDerivs license (http://creativecommons.org/licenses/by-nc-nd/3.0/)

\begin{abstract}
The aim of this paper was to verify if the goodwill (positive or negative) disclosed after a merger or acquisition is sensitive to manipulating the financial result in the acquiring company. Manipulating the result referred to the extent of cost allocation in short-term prepayments. Later we examined if the operational result achieved by the acquiring company (profit or loss) has an impact upon the revealed goodwill. The verification of the research hypotheses was performed with the use of statistical tools (linear regression analysis, nonlinear regression function test, normality of residual distribution test). As a result of the research, no significant relation between allocating costs and the disclosed negative goodwill was found, only in the case of positive goodwill its value was related to the allocating in assets costs. Neither positive nor negative goodwill was related to the operating results of the acquiring companies in one year preceding the merger or acquisition.
\end{abstract}

Keywords: merger, acquisition, goodwill.

\section{Introduction}

Business combinations are the last and most permanent method of concentrating company capital. In this process, out of a few entities (in Poland most business combinations occur between two companies ${ }^{1}$ ) one entity is created. Under the Polish Commercial Companies Code, a business combination involves the deregistration of at least one of the merging companies without conducting the process of its liquidation. The owners of the merging companies introduce the companies' net assets to a company which is called a combined company after the merger, acquiring in exchange the ownership titles to the company which continues its activity after the merger. The participation of each shareholder in exercising control of the company depends on the terms and conditions of the merger, previously negotiated and

\footnotetext{
${ }^{1}$ Based on Dr. Piotr Luty's doctoral dissertation.
} 
included in the merger plan. The key parameter for the division of control after the merger is the ownership title exchange ratio.

According to the ownership title exchange ratio, an exchange of company ownership titles takes place. As a consequence of the merger, the companies lose their legal personalities. The ownership title exchange ratio depends on a previously determined value of one share of the merging companies. Therefore, to find out how many ownership titles the owners of the acquired company are to receive, one needs to know the value of their shares or interests as well as the value of the transferred ownership titles. The valuation method of the merging companies has not been explicitly specified, and its choice is left to the individual judgment of the management boards and the owners of the merging companies. In essence, all the commonly known methods, as well as the individual expert methods, can be considered appropriate for the purpose of determining the exchange ratio providing they are recognised as adequate.

In the case of the acquirer and acquiree companies, the most frequently used methods of valuation include the net asset value method, income methods, as well as multiplier and market comparison methods. Under the abovementioned valuation methods, the net financial result disclosed in the financial statement may influence significantly the estimated value of ownership titles. In the net asset value method, net assets, in terms of value, are equal to equity, i.e. the total capital provided by owners (including, among others, share, supplementary and reserve capital), as well as generated by the company in the course of its regular business (net financial result). The income method consists in discounting the future results of business operations, i.e., depending on the approach, company financial results or cash flows. The market comparison method (multiplier) may take into account "such factors like price-to-earnings ratio and the dividend rate of comparable securities issued by companies with similar characteristics." ${ }^{2}$ The value of ownership title for determining the exchange ratio will, therefore, depend on the company's financial result per share, and/or the $\mathrm{P} / \mathrm{E}$ ratio (price-to-earnings) determined based on the rules of an active capital market.

As a consequence of introducing net assets (accounted for by the purchase method) to the acquiring company in fair value by the owners of the acquired companies and receiving in exchange ownership titles to the acquiring company, goodwill (positive or negative) is created. ${ }^{3}$ The valuation of the ownership titles is already used at the stage of determining the exchange ratio, as well as at the stage of determining the acquisition price (the valuation of the ownership titles transferred by the acquirer). The sensitivity of the valuation of ownership titles to the changes of the financial result (manipulating the financial result) may manifest itself in:

\footnotetext{
${ }^{2}$ UoR (Polish Accounting Act), art. 44 b section 4 item 2.

${ }^{3}$ This paper analyses only those mergers in which the takeover price is expressed exclusively in the ownership titles of the acquiring company.
} 
1. The number of acquirer's shares transferred to the new owners,

2 . The company value (positive or negative) disclosed during the merger process

3. The amount of supplementary capital (agio for new issues of shares)

4. Changes to the financial results in future reporting periods as a result of writing off and accounting for the manipulated asset and liability items.

Financial result manipulation (increasing or decreasing) always appears correspondingly with another item of company assets and liabilities (following the accrual-basis and cost and revenue matching principles). One of many balance sheet positions directly related to the level of the financial result are prepayments and accruals. $^{4}$

In order to verify the impact of manipulating the financial result by acquirers upon the disclosed company value, the following research hypothesis has been formulated:

H1: The goodwill disclosed in the result of a merger depends on the acquiring company's costs allocated in assets.

H2: The goodwill disclosed in the result of a merger depends on the acquiring company's operating results.

The verification of the research hypothesis will include, separately, the positive and negative value of the company.

Business combinations can be accounted for in various ways. The Polish Accounting Act provides for the possibility of including in the takeover price not only the value of the transferred ownership titles of the acquiring company, but also the acquired shares of the acquiree, or any form of payment whose fair value can be estimated. $^{5}$

Based on the literature review it can be stated that the combinations accounted for by the method of ownership title exchange and those accounted for by alternative methods (e.g. by the acquisition of ownership titles from the original owners) differ significantly. Erickson and Wang [Erickson and Wang 1999] ${ }^{6}$ noted that the acquirer companies which transfer their ownership titles in the business combination process manipulate the financial result. Within the group of companies which accounted for the combination in cash, they did not find a significant statistical correlation in manipulating the financial result.

Similarly, the research study into the working capital of merging companies conducted by Louis [Louis 2004] ${ }^{7}$ showed that statistically, significant relations exist only within the group of companies accounting for combinations using ownership titles (no statistically significant relations in the mergers of companies in which the acquisition of ownership titles took place).

\footnotetext{
${ }^{4}$ This paper focuses exclusively on prepayments.

${ }^{5}$ Based on UoR art. 44 b section 5.

${ }^{6}$ Research into U.S. companies, research sample: 55 companies accounting for combination with ownership titles and 64 with cash.

${ }^{7}$ Research into U.S. companies, the research sample included 373 companies.
} 
Botsari and Meek [Botsari, Meek 2008] noted that the companies which account for the combination using ownership titles before the combination takes place, influence the increase of market share price, which later translates into transferring a lower number of shares to the owners of the acquired company.

There are research studies which describe the behaviour of equity value (market values) as a consequence of the disclosure of the merger plan and the anticipated goodwill. Jennings [Jennings 1996] and Henning [Henning 2000] found a positive correlation between equity valuation and disclosed goodwill. It suggests that a positive goodwill is associated with the additional benefits resulting from the business combination.

The research also considered negative goodwill recognised as a consequence of the combination. Negative goodwill is often called a 'bargain purchase' and can result in the post-merger increase of the company financial result. Dunn, Kholbeck and Smith [Dunn, Kholbeck, Smith 2011], following other authors, conclude that negative goodwill can be used for financial result manipulation in order to protect against a decrease in the financial result or a generated net loss.

Most research studies into the impact of disclosed goodwill upon the post-merger company image were conducted in the United States, in Poland there is a lack of research on this subject.

\section{Methodology and research sample}

In order to verify the strength of the statistical relation between the goodwill (positive or negative) disclosed in the result of a business combination and manipulating the financial result, the following statistical tools were used: linear regression analysis, nonlinear regression function test, normality of residual distribution test. These methods are commonly used in the literature for the investigation of statistical relations between variables.

The following variables were chosen:

- GW - goodwill,

- ACC - prepayments,

- ROA - operating result.

In the regression model, the dependent variable will be GW (calculating formula (1)). The GW variable is calculated separately for positive and negative goodwill.

$$
G W=\ln (\text { goodwill }) .
$$

The explanatory variable will be the ACC ratio (calculating formula (2)). The ACC provides information on the proportion of costs (short-term prepayments) incurred one year before the combination which were not accounted for in the financial result. Allocating costs and creating prepayments may influence the financial result manipulation (the larger the proportion of costs allocated, the better the financial result the company achieves). 


$$
\mathrm{ACC}=\frac{\text { Short }- \text { term prepayments }}{\text { operating costs }} .
$$

The ROA 'operating result' variable is intended to answer the question if the disclosed goodwill depends on the operating profit or loss.

$$
R O A=\frac{\text { operating result }}{\text { total assets }} .
$$

The research sample consists of Polish companies in the years 2003-2012. The development of the database was outsourced to the firm InfoCredit by the Accountants' Association in Poland. The database contains companies which entered the information on the merger of the acquisition of another unit in the National Court Register. Such an entry is obligatory for business combinations accounted for in accordance with the Polish Commercial Companies Code and provides for the dissolution of a company without the liquidation procedure. The entry in the Code concerning the business combination confirms that the combination involved a settlement in ownership titles.

The company mergers chosen for analysis were those whose financial statements were available for the periods:

- ' -1 ': one year before the planned business combination

- ' 0 ': the year in which the business combination took place

- ' +1 ': the second year after that in which the business combination took place

Subsequently, companies were selected which revealed positive goodwill (in intangible assets) or negative goodwill (in liability accruals) in their financial statements as a consequence of the merger. The selected companies accounted for the merger using the purchase method. The purchase method is the most commonly used method in Polish business combinations. The research into this topic was carried out by Janowicz [Janowicz 2013].

In the case of mergers and acquisitions, in which no goodwill was created (either positive or negative) the method used to account for the combination could be the pooling of interest method or the combination occurred between companies under shared direct control, where the acquired company had been previously founded by the acquirer.

It is also possible to carry out a merger (and account for it using the purchase method), in which the value of the acquirer's capital transferred to the owners is equal to the value of the acquired net assets, or the acquiring company purchases the ownership titles on the secondary market for the equivalent of the net assets.

The sample consists of 421 acquiring companies. In the database there are 43 mergers and acquisitions revealing positive goodwill and 40 mergers and acquisitions revealing negative goodwill. 


\section{Research results}

In order to verify the hypothesis formulated in the research, the regression analysis was used with the support of the Gretl statistical software.

The research hypothesis stated that positive goodwill revealed as a consequence of a business combination depends on the acquirer's costs allocated in assets. Within the research, a regression model was formulated and the significance and correlations between the explanatory variable and the dependent variables were examined (Table 1).

Table 1. Parameters of the regression function - "positive" goodwill

\begin{tabular}{|l|c|c|c|c|l|}
\hline & Coefficient & Stand. error & $t$-Student & $P$-value & \\
\hline const & 6.0629 & 0.2738 & 22.14 & $<0.0001$ & $* * *$ \\
\hline ACC & 25.8846 & 10.5136 & 2.462 & 0.0177 & $* *$ \\
\hline
\end{tabular}

$* * * \alpha=0.01, * * \alpha=0,05$

Arithmetic mean of dependent variable

6.328018

134.1025

Sum of squared residuals

Co. determ. R-squared

$\mathrm{F}(2,88)$

Logarithm of credibility

Bayesian Inf. Crit.

Source: own study.

Regression function equation:

$$
G W=6,0629+25.8846 \times \text { ACC } .
$$

The test of the non-linear form of the regression function - squares of variables were performed based on the RESET test. The test results indicate that there is no reason to reject the hypothesis about the linear form of the regression function.

The normality test of residual distribution (the Doornik-Hansen test) indicates that there is no basis for rejecting the zero hypothesis that the empirical distributor has a normal distribution (Chi-square $(2)=0.964$ with the value of $p=0.6174$ ) Figure 1.

Based on Figure 1 the conclusion can be made that only one independent variable ACC (allocating costs) has a significant impact upon disclosing positive goodwill as a consequence of a business combination. The research hypothesis states that the negative goodwill which is recognised as a result of a merger or acquisition depends on the costs of the acquiring company allocated in assets. The research involved a regression analysis, as well as the verification of the significance and correlations between the independent variable and dependent variables (Table 2). 


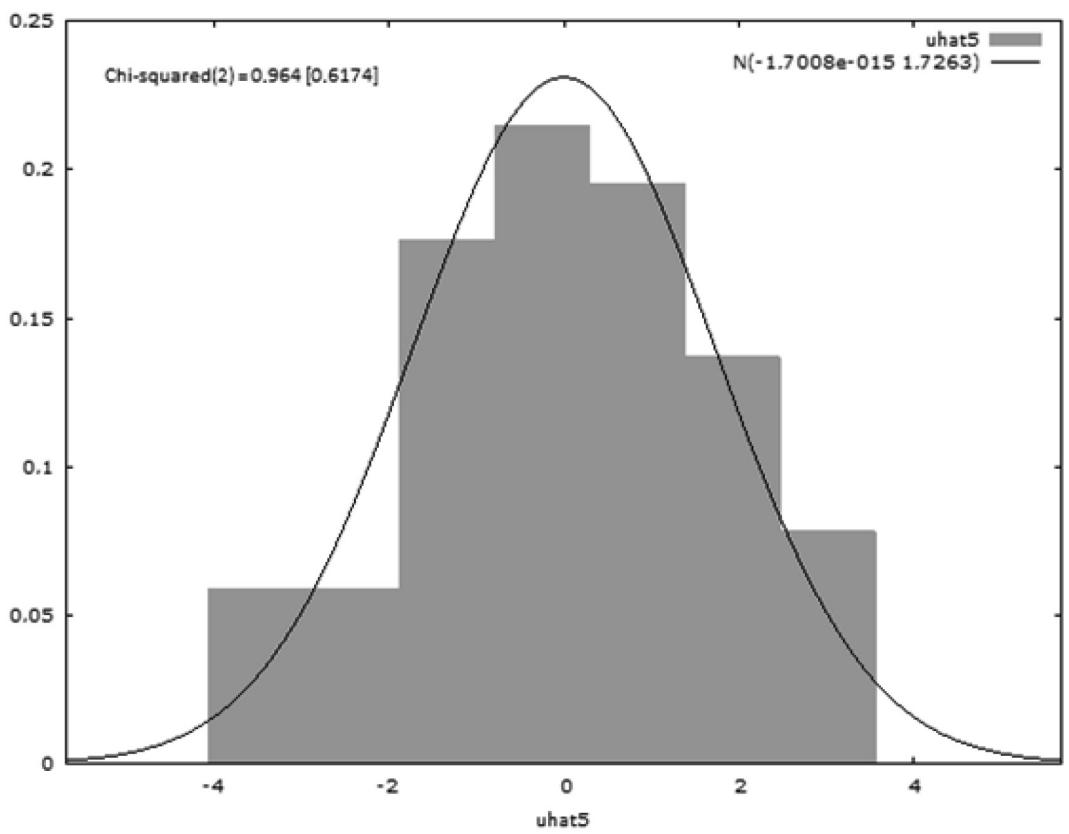

Fig. 1. The normality test of residual distribution - positive goodwill

Source: own study.

Table 2. Parameters of the regression function - "negative" goodwill

\begin{tabular}{|l|c|c|c|c|c|}
\hline & Coefficient & Stand. error & $t$-Student & $P$-value & \\
\hline const & 6.28626 & 0.407252 & 15.4358 & $<0.0001$ & $* * *$ \\
\hline ACC & 5.78918 & 12.501 & 0.4631 & 0.6459 & \\
\hline ROA & 0.880019 & 3.0574 & 0.2878 & 0.7750 & \\
\hline
\end{tabular}

*** $\alpha=0.01, * * \alpha=0.05$

Arithmetic mean of dependent

Standard deviations variable

Sum of squared residuals

209.2971

Standard error of residues

2.316590

Co. determ. R-squared

$0.007469 \quad$ Adjusted R-square

$-0.043430$

$\mathrm{F}(2,88)$

0.146744

p-value for the $F$ test

0.863989

Logarithm of credibility

$-93.32320$

Akaike's crit. inform.

192.6464

Bayesian Inf. Crit.

197.8594

Hannan-Quinn's crit.

194.5572

Source: own study.

The test of the non-linear form of the regression function - squares of variables were performed based on the RESET test. The test results indicate that there is no reason to reject the hypothesis about the linear form of the regression function. 
The normality test of residual distribution (the Doornik-Hansen test) indicates that there is no basis for rejecting the zero hypothesis that the empirical distributor has a normal distribution (Chi-square $(2)=2.643$ with the value of $p=0.2667$ ) Figure 2.

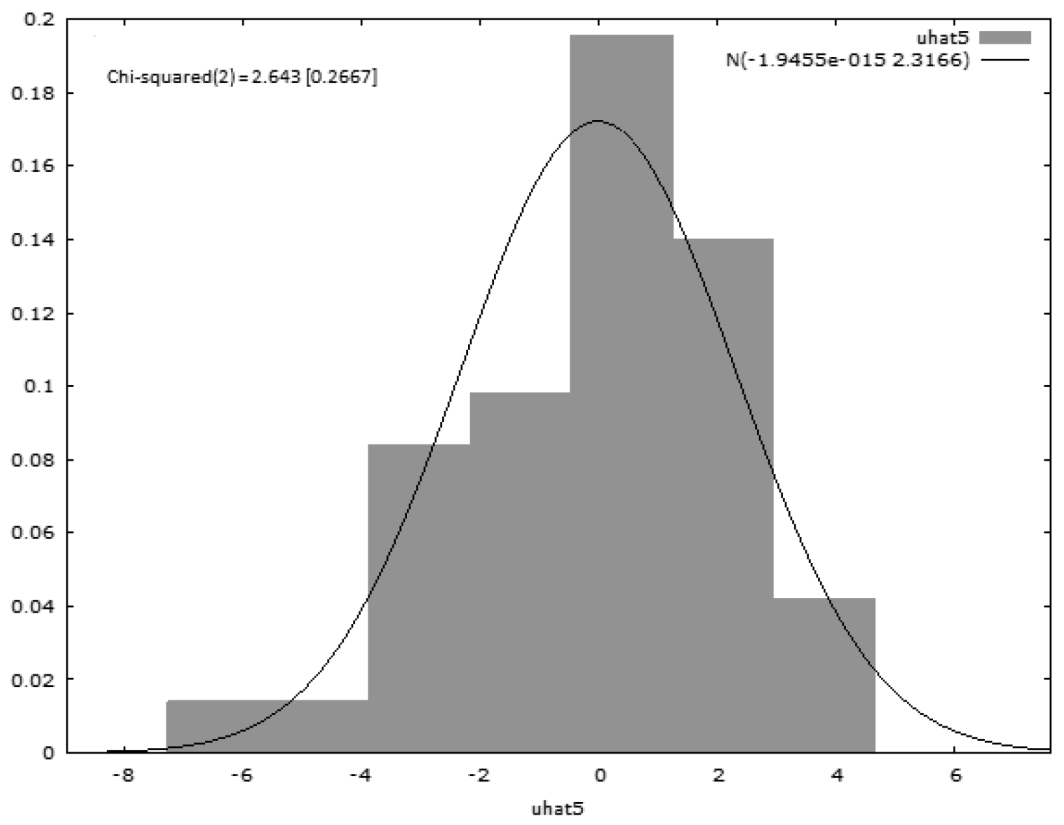

Fig. 2. The normality test of residual distribution - negative goodwill

Source: own study

Based on Table 2 it can be concluded that none of the independent variables significantly describes the dependent variable (negative goodwill in the balance sheet).

\section{Conclusion}

The literature review and the theoretical possibilities to control goodwill in business combinations ${ }^{8}$ may suggest that the companies which plan a merger or an acquisition may manipulate their financial information in order to gain specific benefits.

The aim of this article was to examine if the goodwill (positive or negative) disclosed after a business combination is sensitive to the manipulation of the financial result in the acquiring company. Manipulating the result referred to the scale of

\footnotetext{
${ }^{8}$ Based on the book [Luty, Luty, Markisz 2016].
} 
allocating costs in short-term prepayments. Further, it was verified if the operational result achieved by the acquiring company (profit or loss) has an influence on the revealed goodwill. The article also analysed the influence of the moment of merger or acquisition (the year in which the combination was entered into the National Court Register) upon the disclosed goodwill.

The author expected the existence of the significant relation between cost allocation and the disclosed goodwill. As a result of this research, no significant correlation between allocating costs and the disclosed negative goodwill was found, only in the case of positive goodwill its value was related to the allocating in assets costs. Neither positive nor negative goodwill was related to the operating results of the acquiring companies in the year preceding the merger or acquisition.

The research results do not imply a definite conclusion that the companies which plan a merger or acquisition (including the acquiring company) do not manipulate their financial results. The research results are an introduction to the further analysis of financial result manipulation in business combinations. A sectoral analysis of the merging companies has not been conducted.

\section{Bibliography}

Botsari A., Meeks G., 2008, Do acquirers manage earnings prior to a share for share bid?, Journal of Business Finance and Accounting.

Dunn K., Kohlbeck M.J., Smith T.J., 2011, Bargain Purchase Gains and the Acquisitions of Failed Banks Florida Atlantic University - School of Accounting, Florida Atlantic University - School of Accounting and Florida Atlantic University - School of Accounting.

Erickson M., Wang S., 1999, Earnings management by acquiring firms in stock for stock mergers, Journal of Accounting and Economics, vol. 27, no. 2.

Henning S.L., 2000, Valuation of the components of purchased goodwill, Journal of Accounting Research, vol. 38, no. 2.

Janowicz M., 2013, Prawne połaczenia spółek publicznych w 2011 roku w ich sprawozdaniach finansowych - wyniki badań, Zeszyty Naukowe Uniwersytetu Szczecińskiego, Finanse. Rynki Finansowe. Ubezpieczenia, 61, vol. 1.

Jennings R., 1996, The relation between accounting goodwill numbers and equity values, Journal of Business Finance and Accounting.

Louis H., 2004, Earnings management and the market performance of acquiring firms, Journal of Financial Economics, vol. 74, no. 1.

Luty P., Luty Z., Markisz M., 2016, Podziat, taczenie i przeksztatcenie jednostek w świetle ustawy o rachunkowości i MSSF w aspekcie bilansowym i podatkowym, Accountants' Association in Poland, Warsaw. 


\section{WARTOŚĆ FIRMY W PROCESACH PRZEJĘĆ I POLĄCZEŃ W POLSCE}

Streszczenie: Celem artykułu było sprawdzenie, czy wartość firmy (pozytywna lub negatywna) ujawniona w spółce przejmującej po połączeniu jest wrażliwa na manipulowanie wynikiem finansowym. Manipulowanie wynikiem dotyczy alokacji kosztów w krótkoterminowych rozliczeniach międzyokresowych. W artykule zbadano, czy wynik operacyjny osiągnięty przez spółkę przejmującą (zysk lub strata) ma wpływ na ujawnioną po połączeniu wartość firmy. Weryfikację hipotez badawczych przeprowadzono za pomocą narzędzi statystycznych (analiza regresji liniowej, test nieliniowości funkcji regresji, test normalności rozkładu). W wyniku przeprowadzonych badań nie stwierdzono istotnej zależności między alokacją kosztów a ujawnioną ujemną wartością firmy. W przypadku dodatniej wartości firmy jej wartość była związana z alokacją kosztów aktywów. Ujawniane po połączeniu zarówno dodatnia, jak i ujemna wartość firmy nie były związane z osiąganymi przez spółki przejmujące wynikami operacyjnymi w roku poprzedzającym połączenie.

Słowa kluczowe: połączenie, przejęcie, wartość firmy. 